\title{
Early Developmental Changes in IGF-I, IGF-II, IGF Binding Protein-1, and IGF Binding Protein-3 Concentration in the Cerebrospinal Fluid of Children
}

\author{
R. CLAY BUNN, WILLIAM D. KING, MARGARET K. WINKLER, AND JOHN L. FOWLKES \\ Arkansas Children's Hospital Research Institute [R.C.B., J.L.F.], Department of Pediatrics, University of \\ Arkansas for Medical Sciences, Little Rock, Arkansas 72202; and Department of Pediatrics [W.D.K., \\ M.K.W.], University of Alabama at Birmingham, Birmingham, Alabama 35233
}

\begin{abstract}
IGF-I and IGF-II are ubiquitously expressed growth factors that have profound effects on the growth and differentiation of many cell types and tissues, including cells of the CNS. In biologic fluids, most IGFs are bound to one of six IGF binding proteins (IGFBPs 1-6). Increasing evidence strongly supports a role for IGF-I in CNS development, as it promotes neuronal proliferation and survival. However, little is known about IGF-I and its homolog IGF-II and their carrier proteins, IGFBPs, during the neonatal period in which brain size increases dramatically, myelination takes place, and neurons show limited capacity to proliferate. Herein, we have determined the concentrations of IGF-I, IGF-II, IGFBP-1, and IGFBP-3 in cerebral spinal fluid (CSF) samples that were collected from children who were $1 \mathrm{wk}$ to $18 \mathrm{y}$ of age. The concentrations of IGF-I, IGFBP-1, and IGFBP-3 in CSF from children $<6$ mo of age were significantly higher than in older children, whereas IGF-II was higher in the
\end{abstract}

\section{ABSTRACT}

older group. This is in contrast to what is observed in the peripheral circulation, where IGF-I and IGFBP-3 are low at birth and rise rapidly during the first year, reaching peak levels during puberty. Higher concentrations of IGF-I, IGFBP-1, and IGFBP-3 in the CSF of very young children suggest that these proteins might participate in the active processes of myelination and synapse formation in the developing nervous system. We propose that IGF-I and certain IGFBPs are likely necessary for normal CNS development during critical stages of neonatal brain growth and development. (Pediatr Res 58: 89-93, 2005)
CSF, cerebrospinal fluid
IGFBP, IGF binding protein
IGFR, IGF receptor

Abbreviations
The IGF axis includes two homologous IGFs (IGF-I and IGF-II), at least six high-affinity IGF binding proteins (IGFBP-1, -2, -3, -4, -5, and -6), and two membrane-bound IGF receptors (IGFR1 and IGFR2) (1). IGFs are produced by a wide variety of cells and are found in many biologic fluids (2). IGF-I and IGF-II bind to and activate the IGFR1, an integral membrane tyrosine kinase that when activated triggers intracellular signaling pathways that promote cell division, differentiation, and metabolism (3). Most of the IGF-I and IGF-II in the circulation and other biologic fluids exist in a complex with an IGFBP, which bind to IGFs with affinities 10to 100 -fold greater than the IGFR1, thereby regulating the

Received May 26,2004; accepted September 13, 2004.

Correspondence: R. Clay Bunn, Ph.D., Arkansas Children's Hospital Research Institute, 1120 Marshall Street, Little Rock, AR 72202; e-mail: bunnrobertc@uams.edu.

This work was supported in part by National Institutes of Health Grant R01DK055653 (J.L.F), the Genentech Center for Clinical Research and Education (M.K.W.), National Institutes of Health Grant C06 RR16517 to Arkansas Children's Hospital Research Institute and the Arkansas Biosciences Institute (R.C.B. and J.L.F.).

DOI: 10.1203/01.PDR.0000156369.62787.96 bioactivity of IGFs by preventing their interaction with and activation of the receptor (4).

IGF-I is recognized as a potent neurotrophic factor because of its ability to promote the proliferation, migration, and differentiation of immature glial and neuronal cells (reviewed in Ref. 5). In addition, IGF-I can protect neurons from undergoing apoptotic cell death as a result of a variety of insults (6-8). An important role for IGF-I during CNS development has been revealed by studies in which IGF-I expression in the CNS has been increased or eliminated or where IGF-I bioactivity has been blunted by the overexpression of IGFBPs (9). For example, transgenic mice engineered to overexpress IGF-I in the brain exhibit overgrowth of this tissue (10), increased numbers of neurons and synapses (11-14), and increased myelin content (10). In contrast, elimination of IGF-I expression or reduction of IGF-I bioactivity by overexpression of an IGFBP, such as IGFBP-1, can result in reduced brain growth $(15,16)$ and reduced numbers of neurons and glia $(12,17-19)$.

Several studies have reported alterations in IGF-I or IGFBP levels in cerebrospinal fluid (CSF) from patients with various neurologic disorders (20-22); however, no studies to date have 
reported an association between IGF-I expression in the human CNS with the period of rapid myelination, synaptic organization, and brain growth that is observed during the first few months after birth. Herein, we report our results from a study that examined IGF-I and IGF-II expression in the CSF that was obtained from humans who ranged in age from newborn to $18 \mathrm{y}$. In addition, we analyze the expression level of IGFBP-1 and IGFBP-3 in these individuals. We find that IGF-I, IGFBP-1, and IGFBP-3 levels are highest in CSF from individuals who are younger than 6 mo when compared with children who are 6 mo or older, whereas IGF-II concentrations follow the opposite pattern, being higher in the older group. Furthermore, the concentrations of IGF-I, IGF-II, IGFBP-1, and IGFBP-3 do not vary when compared according to sex or race. The potential relevance of these findings in the context of human CNS development is discussed.

\section{METHODS}

Sample collection. CSF samples $(n=600)$ were obtained from children ( $\leq 18 \mathrm{y}$ of age) who had undergone a routine spinal tap for diagnostic purposes by the inpatient and outpatient services provided at The Children's Hospital of Alabama (Birmingham, AL). Sample collection was approved by the Institutional Review Board at the University of Alabama at Birmingham. Common reasons for performing spinal taps in these children included possible shunt malfunctions, fever, vomiting, headache, seizures, and cancer. All CSF samples were analyzed for the following parameters: total protein, glucose, cell count and differential, and culture as performed in the clinical laboratories of The Children's Hospital of Alabama (Table 1). Only sterile samples that displayed values within established normal ranges for all parameters monitored were used in the analyses (negative Gram's stain, negative culture, absolute white blood cell $\leq 10 / \mathrm{mm}^{3}$, protein $<150$ $\mathrm{mg} / \mathrm{dL}$ for infants and $<50 \mathrm{mg} / \mathrm{dL}$ for children, and glucose $50-100 \%$ of normal serum values; Table 1). Collected CSF samples that did not satisfy these criteria were excluded from this study. A total of 148 normal CSF samples from children who were $<6$ mo of age and 126 normal CSF samples from children who were $>6$ mo of age were used for the various analyses.

ELISAs. IGFBP-1 and IGFBP-3 were measured in CSF samples using kits DSL-10-7800 and DSL-10-6600, respectively, provided by Diagnostic Systems Laboratories (Webster, TX). All measurements were performed in duplicate according to the manufacturer's recommended protocol. IGF-I and IGF-II were measured in duplicate in hydrochloric acid-ethanol extracted CSF samples using kits DSL-10-5600 and DSL-10-2600, respectively, according to the manufacturer's recommended protocol. Average intra-assay coefficients of variation for each assay were $16 \%$ for IGFBP-1, 9\% for IGFBP-3, 19\% for IGF-I, and $17 \%$ for IGF-II. Because of limited quantities of certain CSF samples, not all analytes could be determined for every sample.

Statistics. Mean IGF-I, IGF-II, IGFBP-1, and IGFBP-3 concentrations were calculated and compared for different age groups, races, and sexes. The $t$ test was used to determine the significance of differences in mean concentrations between groups stratified according to age, race, and sex. Two-tailed $p$ values and corresponding 95\% confidence intervals were reported. Pearson correlation analysis was used to detect significant correlations (coefficients) between protein concentration of CSF versus age, IGF-I, IGFBP-I, and IGFBP-3. SAS version 8.2 and SPSS version 10.1 were used for data management and statistical analysis.

\section{RESULTS}

CSF samples that were obtained from diagnostic spinal puncture were used in this study. Only sterile samples that displayed normal values for protein, glucose, and cellular profiles were used for subsequent analyses (Table 1). Three variables (age, sex, and race) were considered as possible contributors to differences in IGF-I, IGF-II, IGFBP-1, and IGFBP-3 concentration in CSF, as these parameters have been shown to variably have an impact on the IGF axis in human serum. CSF from younger children was noted to contain, on average, a higher white blood cell count $(p<0.001)$, lower glucose concentration $(p<0.001)$, and higher protein concentration $(p<0.001)$ versus older children (Table 1$)$.

Significantly higher concentrations of IGF-I were noted in CSF from children who were younger than 6 mo $(10.8 \pm 0.6$ $\mathrm{ng} / \mathrm{mL})$ versus that in children who were 6 mo and older (6.9 $\pm 0.6 \mathrm{ng} / \mathrm{mL} ; p<0.001$; Fig. 1). Similarly, IGFBP-1 and IGFBP-3 were higher in CSF samples from children who were younger than 6 mo compared with older children $[2.3 \pm 0.1$ $\mathrm{ng} / \mathrm{mL}$ versus $1.5 \pm 0.1 \mathrm{ng} / \mathrm{mL}(p<0.001)$ for IGFBP-1 and $15.1 \pm 0.7 \mathrm{ng} / \mathrm{mL}$ versus $9.4 \pm 0.6 \mathrm{ng} / \mathrm{mL}(p<0.001)$ for IGFBP-3; Fig. 1]. In contrast, the concentration of IGF-II was higher in children who were 6 mo or older versus younger children $(20.2 \pm 2.3 \mathrm{ng} / \mathrm{mL}$ versus $12.6 \pm 1.3 \mathrm{ng} / \mathrm{mL} ; p<$ $0.01)$. When data were stratified according to sex or race, no significant differences were observed in any of the measured parameters (Figs. 2 and 3, respectively).

We found that the protein concentration of CSF was negatively correlated with the age of the patient (Pearson correlation coefficient $=-0.306, p<0.001$ ), consistent with previous observations (23). In addition, IGF-I, IGFBP-1, and IGFBP-3 were positively correlated with the protein concentration of the CSF [Pearson correlation coefficients $=0.479(p$ $<0.001), 0.242$ ( $p<0.001)$, and 0.527 ( $p<0.001)$, respectively], raising the possibility that the increased permeability of the blood-brain barrier in young children may be responsible in part for the observed increases in IGF-I, IGFBP-1, and IGFBP-3 in the CSF of children who are younger than 6 mo.

\section{DISCUSSION}

Although IGF-I is universally accepted as a potent neurotrophic agent in the developing nervous system in animal models, previous studies have not assessed changes in IGF or IGFBP levels during the rapid CNS development that occurs during the first few postnatal months in the human. In contrast,

Table 1. Cytologic and biochemical characteristics of CSF samples

\begin{tabular}{|c|c|c|c|c|}
\hline & Red blood cells & White blood cells & Protein & Glucose \\
\hline$<6 \mathrm{mo}$ & $10.84 \pm 1.61(148)$ & $2.84 \pm 0.24(148)$ & $66.11 \pm 2.30(148)$ & $52.51 \pm 0.88(148)$ \\
\hline$\geq 6 \mathrm{mo}$ & $9.10 \pm 1.83(126)$ & $1.04 \pm 0.14(126)^{*}$ & $31.78 \pm 1.28(125)^{*}$ & $66.51 \pm 1.39(125)^{*}$ \\
\hline Black & $9.32 \pm 1.91(100)$ & $2.21 \pm 0.28(100)$ & $50.94 \pm 3.14(100)$ & $60.01 \pm 1.62(100)$ \\
\hline White & $10.89 \pm 1.65(163)$ & $1.89 \pm 0.19(163)$ & $50.26 \pm 2.14(162)$ & $58.22 \pm 1.10(162)$ \\
\hline Female & $9.56 \pm 1.73(129)$ & $2.05 \pm 0.23(129)$ & $48.32 \pm 2.57(128)$ & $59.23 \pm 1.39(128)$ \\
\hline Male & $10.49 \pm 1.69(145)$ & $1.98 \pm 0.21(145)$ & $52.22 \pm 2.31(145)$ & $58.65 \pm 1.17(145)$ \\
\hline
\end{tabular}

All measurements are shown as mean $\pm \operatorname{SD}(n)$.

$* p<0.001$ vs $<6$ mo. 


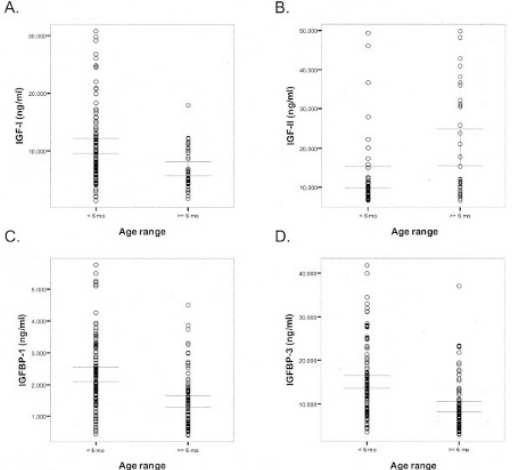

Figure 1. Age dependence of IGF-I, IGF-II, IGFBP-1, and IGFBP-3 concentration in CSF. IGF-I $(A)$, IGF-II $(B)$, IGFBP-1 $(C)$, and IGFBP-3 $(D)$ concentrations were determined in CSF that was obtained from children who ranged in age from $1 \mathrm{wk}$ to $18 \mathrm{y}$. Data from children who were younger than 6 mo were pooled and compared with data from children who were 6 mo and older. Error bars indicate the $95 \%$ confidence interval surrounding the mean value for each age group. The concentration of IGF-I, IGFBP-1, and IGFBP-3 was greater in children who were younger than 6 mo $v s$ children who were 6 mo and older $(p<0.001)$, whereas IGF-II showed the opposite relationship $(p$ $<0.01)$.

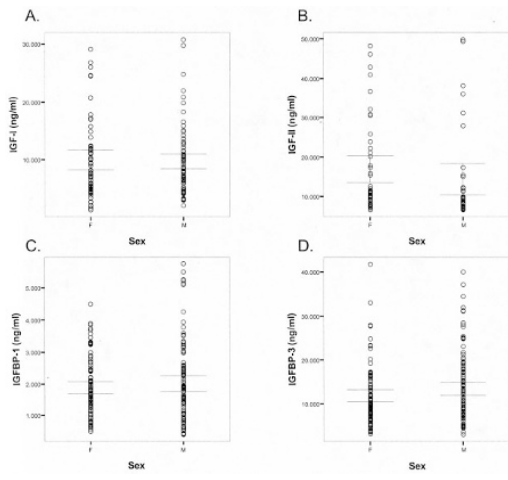

Figure 2. Effect of sex on IGF-I, IGF-II, IGFBP-1, and IGFBP-3 concentration in CSF. IGF-I $(A)$, IGF-II $(B)$, IGFBP-1 $(C)$, and IGFBP-3 $(D)$ concentrations were determined in CSF that was obtained from children who ranged in age from $1 \mathrm{wk}$ to $18 \mathrm{y}$. Data were combined on the basis of the sex of the patients. Error bars indicate the $95 \%$ confidence interval surrounding the mean value for each group. No significant differences in any of the measured parameters was noted between male and female patients $(p>0.05)$.

reduced IGF-I concentration in the CSF has been reported in multiple diseases that affect the human CNS, such as infantile neuronal ceroid lipofuscinosis (20); progressive encephalopathy, hypsarrhythmia, and optic atrophy syndrome (21); and autism (22). Deletion of IGF-I or partial deletions or mutations within the human IGF-I receptor gene that either reduce the number of IGF-I receptors on the cell surface or reduce the receptor affinity for IGF-I have been described. Patients who possess such mutations show various deficiencies in neurologic function in addition to profoundly impaired growth $(24,25)$. Herein, we have shown that the concentrations of IGF-I and two IGFBPs in normal human CSF are highest during the first year of life, which is the most active period of postnatal brain growth (26). This finding lends further support that IGF-I and its regulatory proteins, IGFBPs, likely play an important role in early brain development in humans.

Our estimate of IGF-I concentration in normal CSF is slightly higher than previously reported (27-29), whereas the

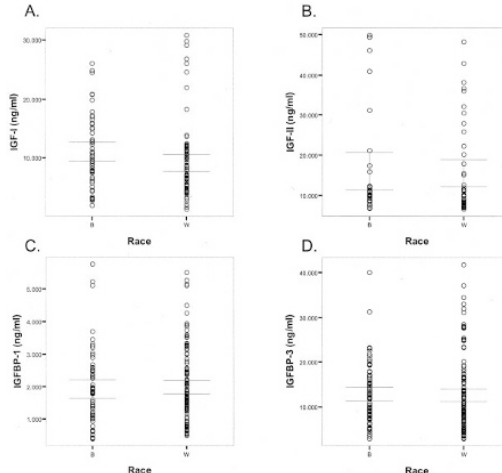

Figure 3. Effect of race on IGF-I, IGF-II, IGFBP-1, and IGFBP-3 concentration in CSF. IGF-I $(A)$, IGF-II $(B)$, IGFBP-1 $(C)$, and IGFBP-3 $(D)$ concentrations were determined in CSF that was obtained from children who ranged in age from $1 \mathrm{w}$ to $18 \mathrm{y}$. Data were combined on the basis of the race of the patients. Error bars indicate the $95 \%$ confidence interval surrounding the mean value for each group. No significant differences in any of the measured parameters was noted between black and white patients $(p>0.05)$.

levels of IGF-II and IGFBP-3 that we detected in normal CSF are similar to previous studies $(28,29)$. Moreover, whereas others have shown that IGF-II occurs in excess over IGF-I in CSF $(28,30)$, we found that the concentration of IGF-I and IGF-II is similar in CSF from children who are younger than 6 mo. Indeed, we found the concentration of IGF-II to be higher in older children compared with those who were younger than $6 \mathrm{mo}$. This finding is of interest because in rodent models, there is strong evidence to support that IGF-I has a predominant role over IGF-II in early CNS development (31). For instance, transgenic mice engineered to overexpress IGF-I in the brain exhibit overgrowth of this tissue (10), increased numbers of neurons and synapses (11-14), and increased myelin content (10). In contrast, elimination of IGF-I expression results in significant reduction in brain mass by 2 mo of age; mice expressing no IGF $\left(\mathrm{IGF}^{-1-}\right)^{--}$) demonstrate brain weights $33 \%$ lower than those of wild-type mice controls (16) and defects in neurologic development (19). A presumed reduction of IGF-I bioactivity through the overexpression of IGFBP-1 results in reduced brain growth (32). However, in our analyses, we show that IGFBP-1 in human CSF is increased in the early months of life, suggesting that it may not normally impair IGF-I action but might function as a reservoir for IGF-I or could assist in the transport of IGFs within the CNS. We also demonstrate that IGFBP-3 is present at higher concentrations in the CNS of children who are younger than 6 mo, suggesting a similar role for this IGFBP. The exact roles of IGFBPs in CNS development have not been well established at this time. Transgenic mice overproducing IGFBP-2, $-3,-4,-5$, and -6 have been studied in this regard: IGFBP-2 transgenic mice show only a modest reduction in brain weight at $5 \mathrm{wk}$ of age (33); no change in brain size has been measured in IGFBP-3 transgenic mice compared with controls (34); IGFBP-6 overexpression targeted to neuronal tissues shows minimal effects in the choroid plexus, hypothalamus, or cortex, yet cerebellum size and weight are reduced by $\sim 25$ and $35 \%$, respectively (35); and, finally, the overproduction of IGFBP-5 in mice early in development actually results in enhanced brain weights, 
whereas other organ sizes are reduced, suggesting that this IGFBP may have differential effects on modulating IGF activity in neuronal tissues (36). Together, these data support that IGFBPs may have an impact in various ways on IGF activity in the developing CNS.

The origin of IGFs and IGFBPs in the CSF is a matter of some debate, with some studies reporting that IGF-I can cross the blood-brain barrier in rats (37), raising the possibility that IGF-I in the CSF could be derived from peripheral sources such as serum, whereas several studies have clearly shown that components of the IGF axis are synthesized in the CNS (reviewed in Ref. 5). In the peripheral circulation, the major source of IGF-I and IGFBP-3 is the liver, where their synthesis is regulated mainly by growth hormone, whereas the production of IGFBP-1 is inversely related to circulating insulin levels. Elevated GH concentrations observed in the CSF of pubertal children compared with younger children $(29,38)$ evidently does not correlate with higher CSF IGF-I concentrations in this age group. It is interesting that Heinze et al. (29) showed that GH in the CSF was higher in the perinatal period and declined to baseline values after age $1 \mathrm{y}$, before rising to peak levels during puberty. Therefore, high GH concentration in the brains of children who are younger than 6 mo might explain the high IGF-I and IGFBP-3 values reported herein, if indeed their transcription is under the regulation of $\mathrm{GH}$ in neuronal tissues. The total protein concentration in CSF is twice as high in full-term neonates than in adults, despite lower plasma protein concentration in neonates compared with adults, indicating that the choroid plexus is significantly more permeable in the newborn period (23); therefore, another potential explanation for our observations is that high concentrations of IGF-I in the CSF may simply reflect greater permeability of the blood-brain barrier, which is supported by the fact that IGF-I and CSF total protein are highly correlated. In contrast, serum concentrations of IGF-I and IGFBP-3 increase $\sim 6-$ and 2-fold, respectively, from birth until maximal levels are achieved during puberty (39), supporting the concept that as the blood-brain barrier matures, a steeper gradient for IGF-I and IGFBP-3 is achieved. Another possibility of how IGFs might be transported into the CSF in a more specific manner is based on the findings that IGFBPs are produced and localized in the choroid plexus $(37,40,41)$ and that IGF uptake into the CSF from the circulation is saturable (42). It has been speculated that the presence of IGFBPs in the choroid plexus allows for facilitated transport of IGFs across the blood-brain barrier and into the CNS. However, mutations within IGF-I that greatly reduce its affinity for IGFBPs or IGF1R have no appreciable effect on transport across the blood-brain barrier (42), suggesting that interaction with IGFBPs or IGF1R may not be a prerequisite for passage of circulating IGF-I into the CSF. Regardless of the mechanism, a high concentration of IGF-I and IGFBPs in the CSF during the first few months of life in the human may help to regulate and promote the vigorous synaptic rearrangement and myelination that occurs during this critical window in CNS development in humans.
Acknowledgments. We thank Beverly Word and Joanie Barnett for technical assistance in performing assays and collecting patient samples. We also thank Dr. Susan Durham for advice while conducting these studies and Diagnostic Systems Laboratories for provision of the assay kits used in this study.

\section{REFERENCES}

1. Jones JI, Clemmons DR 1995 Insulin-like growth factors and their binding proteins: biological actions. Endocr Rev 16:3-34

2. Rechler MM 1993 Insulin-like growth factor binding proteins. Vitam Horm 47:1-114

3. LeRoith D, Werner H, Beitner-Johnson D, Roberts CT Jr 1995 Molecular and cellular aspects of the insulin-like growth factor I receptor. Endocr Rev 16:143-163

4. Mohan S, Baylink DJ 2002 IGF-binding proteins are multifunctional and act via IGF-dependent and -independent mechanisms. J Endocrinol 175:19-31

5. Anlar B, Sullivan KA, Feldman EL 1999 Insulin-like growth factor-I and central nervous system development. Horm Metab Res 31:120-125

6. Matthews CC, Odeh HM, Feldman EL 1997 Insulin-like growth factor-I is an osmoprotectant in human neuroblastoma cells. Neuroscience 79:525-534

7. D'Mello SR, Galli C, Ciotti T, Calissano P 1993 Induction of apoptosis in cerebellar granule neurons by low potassium: inhibition of death by insulin-like growth factor I and cAMP. Proc Natl Acad Sci USA 90:10989-10993

8. Dore S, Kar S, Quirion R 1997 Insulin-like growth factor I protects and rescues hippocampal neurons against beta-amyloid-and human amylin-induced toxicity. Proc Natl Acad Sci USA 94:4772-4777

9. D'Ercole AJ, Ye P, O'Kusky JR 2002 Mutant mouse models of insulin-like growth factor actions in the central nervous system. Neuropeptides 36:209-220

10. Carson MJ, Behringer RR, Brinster RL, McMorris FA 1993 Insulin-like growth factor I increases brain growth and central nervous system myelination in transgenic mice. Neuron 10:729-740

11. Dentremont KD, Ye P, D'Ercole AJ, O'Kusky JR 1999 Increased insulin-like growth factor-I (IGF-I) expression during early postnatal development differentially increases neuron number and growth in medullary nuclei of the mouse. Brain Res Dev Brain Res 114:135-141

12. Gutierrez-Ospina G, Calikoglu AS, Ye P, D'Ercole AJ 1996 In vivo effects of insulin-like growth factor-I on the development of sensory pathways: analysis of the primary somatic sensory cortex (S1) of transgenic mice. Endocrinology 137:54845492

13. O'Kusky JR, Ye P, D'Ercole AJ 2000 Insulin-like growth factor-I promotes neurogenesis and synaptogenesis in the hippocampal dentate gyrus during postnatal development. J Neurosci 20:8435-8442

14. Ye P, Xing Y, Dai Z, D'Ercole AJ 1996 In vivo actions of insulin-like growth factor-I (IGF-I) on cerebellum development in transgenic mice: evidence that IGF-I increases proliferation of granule cell progenitors. Brain Res Dev Brain Res 95:44-54

15. Baker J, Liu JP, Robertson EJ, Efstratiadis A 1993 Role of insulin-like growth factors in embryonic and postnatal growth. Cell 75:73-82

16. Liu JP, Baker J, Perkins AS, Robertson EJ, Efstratiadis A 1993 Mice carrying null mutations of the genes encoding insulin-like growth factor I (Igf-1) and type 1 IGF receptor (Igf1r). Cell 75:59-72

17. Ni W, Rajkumar K, Nagy JI, Murphy LJ 1997 Impaired brain development and reduced astrocyte response to injury in transgenic mice expressing IGF binding protein-1. Brain Res 769:97-107

18. Camarero G, Avendano C, Fernandez-Moreno C, Villar A, Contreras J, de Pablo F, Pichel JG, Varela-Nieto I 2001 Delayed inner ear maturation and neuronal loss in postnatal Igf-1-deficient mice. J Neurosci 21:7630-7641

19. Beck KD, Powell-Braxton L, Widmer HR, Valverde J, Hefti F 1995 Igf1 gene disruption results in reduced brain size, CNS hypomyelination, and loss of hippocampal granule and striatal parvalbumin-containing neurons. Neuron 14:717-730

20. Riikonen R, Vanhanen SL, Tyynela J, Santavuori P, Turpeinen U 2000 CSF insulinlike growth factor-1 in infantile neuronal ceroid lipofuscinosis. Neurology 54:18281832

21. Riikonen R, Somer M, Turpeinen U 1999 Low insulin-like growth factor (IGF-1) in the cerebrospinal fluid of children with progressive encephalopathy, hypsarrhythmia, and optic atrophy (PEHO) syndrome and cerebellar degeneration. Epilepsia 40:16421648

22. Vanhala R, Turpeinen U, Riikonen R 2001 Low levels of insulin-like growth factor-I in cerebrospinal fluid in children with autism. Dev Med Child Neurol 43:614-616

23. Saunders NR, Dziegielewska KM 1998 Transport in the developing brain. In Pardridge WM (ed) Introduction to the Blood-Brain Barrier: Methodology, Biology and Pathology. University Press, Cambridge, pp 277-289

24. Abuzzahab MJ, Schneider A, Goddard A, Grigorescu F, Lautier C, Keller E, Kiess W, Klammt J, Kratzsch J, Osgood D, Pfaffle R, Raile K, Seidel B, Smith RJ, Chernausek SD; Intrauterine Growth Retardation (IUGR) Study Group 2003 IGF-I receptor mutations resulting in intrauterine and postnatal growth retardation. $\mathrm{N}$ Engl J Med 349:2211-2222

25. Woods KA, Camacho-Hubner C, Savage MO, Clark AJ 1996 Intrauterine growth retardation and postnatal growth failure associated with deletion of the insulin-like growth factor I gene. N Engl J Med 335:1363-1367

26. Dekaban AS 1978 Changes in brain weights during the span of human life: relation of brain weights to body heights and body weights. Ann Neurol 4:345-356 
27. Backstrom M, Hall K, Sara V 1984 Somatomedin levels in cerebrospinal fluid from adults with pituitary disorders. Acta Endocrinol (Copenh) 107:171-178

28. Muller HL, Oh Y, Gargosky SE, Lehrnbecher T, Hintz RL, Rosenfeld RG 1993 Concentrations of insulin-like growth factor (IGF)-binding protein-3 (IGFBP-3), IGF, and IGFBP-3 protease activity in cerebrospinal fluid of children with leukemia, central nervous system tumor, or meningitis. J Clin Endocrinol Metab 77:1113-1119

29. Heinze E, Boker M, Blum W, Behnisch W, Schulz A, Urban J, Mauch E 1998 GH, IGF-I, IGFBP-3 and IGFBP-2 in cerebrospinal fluid of infants, during puberty and in adults. Exp Clin Endocrinol Diabetes 106:197-202

30. Tham A, Nordberg A, Grissom FE, Carlsson-Skwirut C, Viitanen M, Sara VR 1993 Insulin-like growth factors and insulin-like growth factor binding proteins in cerebrospinal fluid and serum of patients with dementia of the Alzheimer type. J Neural Transm Park Dis Dement Sect 5:165-176

31. Dupont J, Holzenberger M 2003 Biology of insulin-like growth factors in development. Birth Defects Res Part C Embryo Today 69:257-271

32. D'Ercole AJ, Dai Z, Xing Y, Boney C, Wilkie MB, Lauder JM, Han VK, Clemmons DR 1994 Brain growth retardation due to the expression of human insulin like growth factor binding protein-1 in transgenic mice: an in vivo model for the analysis of IGF function in the brain. Brain Res Dev Brain Res 82:213-222

33. Hoeflich A, Nedbal S, Blum WF, Erhard M, Lahm H, Brem G, Kolb HJ, Wanke R, Wolf E 2001 Growth inhibition in giant growth hormone transgenic mice by overexpression of insulin-like growth factor-binding protein-2. Endocrinology 142:1889-1898

34. Murphy LJ, Rajkumar K, Molnar P 1995 Phenotypic manifestations of insulin-like growth factor binding protein-1 (IGFBP-1) and IGFBP-3 overexpression in transgenic mice. Prog Growth Factor Res 6:425-432

35. Bienvenu G, Seurin D, Grellier P, Froment P, Baudrimont M, Monget P, Le Bouc Y, Babajko S 2004 Insulin-like growth factor binding protein-6 transgenic mice: post- natal growth, brain development, and reproduction abnormalities. Endocrinology $145: 2412-2420$

36. Salih DA, Tripathi G, Holding C, Szestak TA, Gonzalez MI, Carter EJ, Cobb LJ, Eisemann JE, Pell JM 2004 Insulin-like growth factor-binding protein 5 (Igfbp5) compromises survival, growth, muscle development, and fertility in mice. Proc Nat Acad Sci USA 101:4314-4319

37. Reinhardt RR, Bondy CA 1994 Insulin-like growth factors cross the blood-brain barrier. Endocrinology 135:1753-1761

38. Johansson JO, Larson G, Andersson M, Elmgren A, Hynsjo L, Lindahl A, Lundberg PA, Isaksson OG, Lindstedt S, Bengtsson BA 1995 Treatment of growth hormonedeficient adults with recombinant human growth hormone increases the concentration of growth hormone in the cerebrospinal fluid and affects neurotransmitters. Neuroendocrinology 61:57-66

39. Juul A, Dalgaard P, Blum WF, Bang P, Hall K, Michaelsen KF, Muller J, Skakkebaek NE 1995 Serum levels of insulin-like growth factor (IGF)-binding protein-3 (IGFBP-3) in healthy infants, children, and adolescents: the relation to IGF-I, IGF-II, IGFBP-1, IGFBP-2, age, sex, body mass index, and pubertal maturation. J Clin Endocrinol Metab 80:2534-2542

40. Logan A, Gonzalez AM, Hill DJ, Berry M, Gregson NA, Baird A 1994 Coordinated pattern of expression and localization of insulin-like growth factor-II (IGF-II) and IGF-binding protein-2 in the adult rat brain. Endocrinology 135:2255-2264

41. Lee WH, Michels KM, Bondy CA 1993 Localization of insulin-like growth factor binding protein-2 messenger RNA during postnatal brain development: correlation with insulin-like growth factors I and II. Neuroscience 53:251-265

42. Pulford BE, Ishii DN 2001 Uptake of circulating insulin-like growth factors (IGFs) into cerebrospinal fluid appears to be independent of the IGF receptors as well as IGF-binding proteins. Endocrinology 142:213-220 